International Journal of Advanced Academic Research (Sciences, Technology and Engineering) | ISSN: 2488-9849

Journal DOI: 10.46654/ij.24889849

Vol. 6, Issue 12 (December, 2020)|www.ijaar.org

Article DOI: 10.46654/ij.24889849.e61240

\title{
PLANT BIOACTIVE CHEMICALS FOR ANTI-FUNGAL AND BIOFUNGICIDAL POTENCIES: A REVIEW
}

\author{
Felicia Wugo Nmom ${ }^{1}$ and Mercy Gospel Ajuru ${ }^{1 *}$ \\ ${ }^{\mathbf{1}}$ Department of Plant Science and Biotechnology, Rivers State University, Nkpolu-Oroworukwo, \\ P.M.B. 5080, Port Harcourt, Rivers state, Nigeria.
}

\author{
*Corresponding Author: Mercy Gospel Ajuru \\ E-mail: ajurumercygospel@yahoo.com \\ Phone no: +2347036834588
}

\begin{abstract}
Fungi are the major infectious agents of plant diseases causing significant economic loses to farmers and nations alike. These plant fungal diseases are mostly treated with synthetic chemicals. However, indiscriminate use of these chemicals has increased fungi resistance in plants; constitute residues in plants, their fruits and the environment, and consequently has negative impact on the health of consumers as well as the eco-system. This has led to the drive to search for plant bioactive chemicals which are biodegradable and eco-friendly. Organic products have been researched for use as safe alternative to the use of synthetic chemicals for use and management of plant diseases. The products are not harmful to the health of man and his environment. This paper reviews the bioactive compounds of plants for anti-fungal and biofungicidal potencies for plant disease management and the mode of actions of these compounds. From the findings of this study, there are myriads of plant species with bioactive chemicals. This review also revealed that the bioactive compounds are capable of depleting the metals of the pathogens; make them loose their membrane integrity; compete with the fungal pathogen's steroids to inhibit their spore germinations; cause damage to the fungal plasma membrane, DNA and cytoplasmic granulation, disrupt plasma membrane and leakage of cellular contents. The bioactive compounds also inhibit fungal ATpases, resulting to the dissolution of fungal chaperones and co- chaperones which are the second proteins of fungal cytoskeleton. The mode of actions of the bioactive chemicals show they are effective, without any destructive impact on the consumer and the ecosystem. Based on the findings in this review, the use of plant organic chemicals is recommended as sustainable alternative for the management of plant fungal diseases.
\end{abstract}

Keywords: Eco-friendly, Fungal diseases, Organic products, Plant bioactive chemicals, Plant disease management. 


\section{Introduction}

Fungi are wide spread in nature and can be found either indoors or outdoors, occurring as saprophytes or pathogens. Phytopathogenic fungi are the primary agents of plant diseases causing alterations during developmental stages ranging from reproduction to harvest. In fruits and vegetables, there is a wide range of varieties of fungal genera causing quality problems related to nutritional value, organoleptic characteristics and limited shelf life (Agrois, 2004; Gonen etal, 1999; Lopes and Martins, 2008; Maria, et al, 2019; Satish et al, 2007).

Fungal infections cause significant losses in economic crops as their parasitism in plants account for approximately a half or total economic losses in crop and post harvest management (Alfren and Van, 2001). Some frequently encountered plant fungal diseases include anthracnose, leaf and stem rusts, powdery and downy mildews, brown rots, angular leaf spots, white moulds by

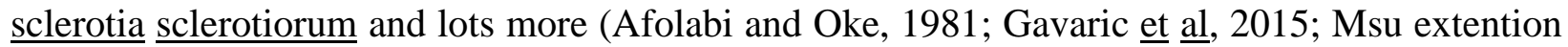
2002; Riad et al. 2014; Zaker 2014).

Plant fungal diseases leave our agricultural forests, grasslands and urban landscapes diminished in economic values and beauty as they cause tremendous damages (Agrois, 2005). In order to curb these damages done to crop plants; farmers are continuously engaged in the indiscriminate usage of synthetic agro-chemicals. Most of these synthetic antifungal used in agriculture belong to the 'azoles' group. These azoles' groups are grouped into two major types: Triazoles and imidazoles. The first group has a broad spectrum of actions, and its function is to inhibit sterol biosynthesis in the plant cell plasma membrane; resulting in the alteration of cell formation and structure; while the second group inhibit the cell division mechanism (mitosis) by disrupting the biosynthesis and the mitotic spindle consequently (Daniel et al, 2015; Diaz-Dellavalle et al,2011; Thompson 2002; Trosken et al 2004; Tzortzakis and Economakis, 2007). It is through this mechanism of action of azoles that food preservation in the plant against fungal growth and protection of the plant is made possible (Daferera, 2003; Daniel et al, 2015; Korres et al. 2011; Trosken et al, 2004). In this way, plants can be protected from fungal attacks by synthetic chemical actions, subsequent increase in crop yields. In spite of this advantage, the synthetic chemicals have greater disadvantages to the plants, consumers and the ecosystem. Toxic wastes in both plants and their fruits after chemical application reside in them and persistent usage of the plant produce soon raise concerns health wise on the consumers especially as fruits and vegetables are consumed in relatively short time after harvest.

It has also been established by national academy for science (NAS) that synthetic chemical residues remain in food and could be carcinogenic and as such, are considered to be hazardous to human health and the ecosystem (Aala et al, 2010; Jassode Rodriguez et al, 2015; Thangavelu et al, 2013). Additionally, abuse and indiscriminate use of these chemicals could generate resistance in the phytopathogenic fungi (Aala et al, 2010; Hamowia and Safran, 1994; Zaker, 2004). Since the synthetic chemicals are not biodegradable, they persist for years in the environment altering the organized nature of the environment.

It was these negative impacts of the chemicals that actually gave rise to the drive to seeking for organic compounds which can quickly turn antifungal chemicals to organic molecules 
(biodegradable) in the environment, therefore interest became generated to researching organic and useful bio-products that can manage and control plant fungal diseases, thereby sustaining the human consumer health and eco-friendship.

Based on the fore-goings, this paper reviewed plant bio-active compounds for antifungal and biofungicides; identified plant species which bioactive compounds are antifungal and biofungicidal; as well as review the mode of their actions and subsequent recommendations as safe alternative biodegradable, affordable, available and eco-friendly compounds to field inventories.

\section{Defects of Synthetic Field Inventories}

Chemical controls of most fungal diseases of plant maybe available and could extensively reduce the impact of the pathogenic attacks on plants; but field applications of these chemicals are not desirable owing to their adverse effect to consumers and the environment. Some of the defects include:

1.) The chemical residues of the compounds persist for years both in the plant and their products and these have been identified as carcinogenic, posing health hazards to man and the environment where the residues remain for years and are considered as non eco-friendly.

2.) The indiscriminate use generates pathogen-resistance to the chemicals.

3.) They are not readily biodegradable.

4.) They cannot be used for organic fruit production along the lawns.

5.) High cost; cost about $20 \%$ of the production cost is spent on synthetic chemicals.

6.) The increasing demands of production and the regulations on the use of agro-chemicals (Harris et al., 2001; Hof, 2001).

New antifungal compounds, with distinct mode of actions, such as the ability to turn the bioactive compounds into organic molecules are sought for from plants. These plants with the bio active compounds, however, are sought for alternative use (Afolabi and oke, 1981).

\section{The Preference For Plant Bioactve Chemicals}

In order to reduce and possibly exclude the use of synthetic chemical antifungal, the need to study the bio-products and their sources which exhibit antifungal and biofungicidal potentials is very important; hence plants have physiological properties or defense mechanism which functions allow them metabolize active compounds generating protection against pathogens, thereby preventing pathogen invasions (Maria Fernanda et al, 2019). In addition, the metabolites are not harmful to health neither do they constitute ecological hazards. These are therefore considered as an excellent alternative for the management of phytopathogenic fungi (Bennett and Wallsgrove, 1994).

\section{Anti -fungal Bioactive Compounds}

Higher plants are rich sources of bioactive chemical compounds, some of which are from aromatic and medicinal plants. These compounds occur as secondary metabolites in a wide range 
of variety. Plant secondary metabolites have great potentials as a source of effective antifungal

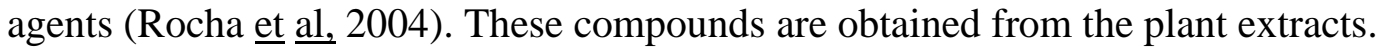

Plant extracts and essential oils contain secondary compounds metabolized by plants. These compounds are stored in plants cell vacoules, such that when those plant materials (leaves, roots, buds, flowers) are used in form of extract from the materials, they have the potentials for antifungal and biofungicides.

Plant secondary metabolites are basically grouped into three; according to their biosynthetic origins, as:

1.) Terpenoids (nitrogen - containing compounds)

2.) Phenyl-propanoids (phenolic compounds).

3.) Cyanohydrins (Croteau et al, 2000).

The most important building blocks employed in the biosynthesis of plant secondary metabolites are derived from acetyl coenzyme A; Shikimic and Malvalonic acids and 1-doxyxylulose-5phosphate utilized in the acetate shikimate, mevalonate and deoxy-xylulase phosphate pathways (Croteau et al, 2000; Dewicks 2002). Several reports indicate that these compounds possess antifungal potencies. The plant tissues could be the roots, stems, barks, leaves, fruits, buds stalks or pods (Davicino et al, 2002).

The plant materials could also be used in form of powder to control plant fungal pathogens or preserve the shelf lives of post-harvest products (Okogbule and Chuku, 2019). These organic bioactive compounds consist of low molecular weights and are regarded as non-essential in sustaining plant life; but crucial for the survival of the producing organisms (Hadacek, 2002).These compounds are frequently accumulated by plants in smaller quantities than the primary metabolites (Croteau et al, 2000; Dewick, 2002).

There are several examples from literature of the active compounds within plant extracts and essential oils which can produce the intended effect on plant pathogenic fungi (Crotoras et al, 2004; De-lange et al, 1976; Gillitzer et aㅣ, 2012).

These bioactive compounds include: indole-type of alkaloids, malicin, nemaazals, tannins, flavonoids, coumarins anthraquinones, lectins monoterpene polypeptides, citral, resins, glycocides, saponnins, gums, phenolic compounds, essential oils, for instance, thymol (carvacrol monoterpenoid phenol with odour, Oregano (oreganum vulgare). These compounds have antifungal potencies against Botrytis cinerea and Fusarium species. They can also be used individually as fungicides for fruits and vegetables pathogens. Also, T-muurolol and $\alpha$-cadinol compounds from Calocedrus macrolepsis var formason oil exhibit antifungal effect on Rhizoctonia solani and $F$. oxysporium. More of the compounds can inhibit the mycelial growth of F. Solani, Pestalotiopsis funerea, Colletothricum gleosporiodes and Ganoderma austrate. This implies that these two compounds (T-muurolol and $\alpha$-cadinol) could also be used as a natural bio-alternative control against a broad spectrum of plant pathogenic fungi (Maria Fernanda et al, 2019; Chang et al, 2013 Martinez, 2012; Romanazzi et al, 2012; Armah et al, 1999; Adrian, 1976 and 1977). 


\section{Biofungicidal Bioactive Compounds}

Chemical control of most fungal diseases of crop plants may be available and could extensively reduce the impact of plant diseases; but field application of synthetic fungicides may not always be desirable due to their hazardous effect on human health and the impact of their residues on the ecosystem (Zaker, 2014).

Natural or organic products from plant bioactive compounds (as biofungicides) have been found effective in plants disease management and could be safely incorporated as suitable alternatives for synthetic fungicides. It is estimated that there are more than 250,000 higher plant species on earth that can be evaluated for their ant-microbial bioactive chemical compounds. Over some decades, researchers have evaluated plant extracts and essential oils against plant pathogens, yet efforts are still needed for production of more commercially botanical fungicides in near future (Zaker, 2014; Farombi, 2003). These compounds are biodegradable and eco friendly. They are organic in origin and have minimal (if any) adverse effects on the physiological processes of plants and are easily convertible into common eco-friendly organic materials (Gnanamanickam, 2002).

Plant extracts, essential oils, gums, resins etc have been shown to exert biological activity against plant fungal pathogens. The bio-fungicide could be tried and used both in vivo and in vitro (Fawzi et al, 2009; Jalile et al, 2010; Romanazi et al, 2002).

There are several reports on the efficacy of these bioactive plant products in managing fungal growth in plants as well as mycotoxin production. Some common instances include: cinnamon, clove, oregano, Palma Rosa and lemongrass oils (Marin et al, 2004); tea tree oil (Burgiel and Smaglowski, 2008); common thymes, cinnamon leaf ani seed oils (closic et al, 2010); basil, neem, eucalyptus, dalura, garlic and oleander extracts (Nashwa and Abo-Elyousr, 2012; Lambers et al, 2000). Thymol and carvacrol seem to be the most potent active constituents against plant fungal pathogens that have been reported (Numpaque et al 2011; Shin et al, 2014; Villaanueva et al 2015; Gevaric et al 2015: Balakumar et al, 2011).

It has also been reported of the extracts of clove bud, cinnamon, ginger, black pepper, garlic and onion have effects on Aspergillus niger (Avasthi et al, 2010). The combinations of neem, China berry, garlic, tumeric extracts controlled the growth of Fussarium oxysporium and Rhizoctonia solani (Hadian, 2012). Tsao and Zhou (2000) also repored that extracts combinations of carvacrol, eugenol, citronellol, geraniol, Citral, perillyl and mentol was potent in controlling Monilinia fructicola and Botrytis cinerea. (Zaker and Mosallanejad, 2010).

\section{Plant Species With Bioactive Anti Fungal and Biofungicidal Potencies Against Plant Diseases}

Right from antiquity, plants have been known and used as bioactive compounds, sometimes in folk medicines and food preservatives. Some aromatic and medicinal plants known as herbs and spices contain many biologically active compounds. Extracts and essential oils of plant tissues 
have been reported effective against many pathogenic fungi. These plant species among the many thousands include: many Species of Asteraceae, Piperaceae among which are: Piper angustifolum Lam, Blumed baisamifera, Campotheca acuminata, Capsicum frutescens, Ficus exasperata, Brassica compestris, Ageratum conyzoides, Azadirachta indica, Cassia toria, Catharanthus roseus, Aloe vera, Phyllanthus amarus Moringa oleifera, Euphorbia tirucalli, Pongnia pinata, Piper nigrum, xylopia aethiopicum, Aegle marmelos, Agapanthus africanus, Brazillian savanna plant, Flourcusia microphyll, Acalypha indica, Zingiplus jujube, Vitax agundu, Tagetes natula, Xylotteca krausiana, Zuccagnia brazillian, Cymbopogon retinophutta, oregano, anise, cinnamon, Rosemary, sage artemisa апииa, etc. There are over 250,000 plant species with bioactive potencies (Ikpene et al, 2013; Eferpi et al, 2012; Nmom and Ajuru, 2019; Dellavalla et al, 2011; Cotoras, 2004; Lec et al, 2007).

\section{Mode of Actions of The Plant Bioactive Compounds in The Control of Pathogenic Fungi}

It is severally reported as this study also reveals that a variety of plant bioactive compounds which occur as plant secondary metabolites have antifungal and biofungicidal potencies against phytopathological pathogens it is important to report the mode of actions of the revealed compounds in order to take bioactive chemical studies to elaborate state.

Engelmeier and Hadacek (2006), reported that plant bioactive compounds act on the phytopathological pathogens by interfering with the molecular targets in the pathogens tissues and cells. They also added that the major targets are the fungal biomembrane, proteins and the nucleic acid.

Nmom and Ajuru (2019) reported that saponins, tannins, resins, glycosides, flavonoids and anthracquinones extracted from the leaves of Ficus exasperata on Vernonia amygdalina (bitter leaf plant) were effective by inhibiting cutinases and laccases production by the phytopathogenic fungi.

Davidson (1997) also reported that the toxicity action pathway of tannins attack fungal pathogens directly on the cell membrane by metal depletion of the attacking pathogen. Fungi attack plant cutins by synthesizing cutinases and laccases; and according to Goetz et al (1999) and Bostock et al(1999), the plant bioactive compounds when applied, act by inhibiting the production of cutinases and laccases pathways with which the pathogen uses to degrade the plant cell walls for further destructions; but by the inhibition of the synthesis of the enzymes, the bioactive chemical efficiently protect the plant from fungal damages on the crop plant.

Keukens et al, (1992) proposed that steroidal glycol alkaloids in plant extracts was effective against plant fungal pathogens by interfering with the fungal membrane integrity. They also reported that saponin-steroids complex interacts with sugar residues of the saponin molecules for greater reactions. This is because the sugar chain attached to C-3 is usually critical for both membranes. (plant/pathogen) permeability and the antifungal chemicals in saponins, hence according to them; care must be taken when extracting the plant materials, so as not to remove the sugar residues which may result in biological inactivity of the bioactive chemical. 
Bar-Nun and Meyer (1990) reported that the cyclic triterpenoids (also known as saponins) in form of steroids, steroidal alkaloids glycosalate and cucurbitacins I and D are effective to hinder the induction of extracellular laccase formation of some fungi such as Botrytis cinerea. They added that the extracts of Ecballium elatrium is a ready source of cucurbitacins I which was applied to cabbage and cucumber fruits and plants before inoculation with B. cinerea; prevented and restricted the fungi to the site of infection without spreading. This implies laccase formation by the fungus. It also implies that the bioactive chemical in E elatrium extract acted majorly by phytoauticipin. According to Zhao et al, (2010), Mechanism of action of cucurbitacins I lies in its ability to complex with the steroids of the fungal membrane.

Luo et al (2002) proposed a mechanism of action of monoterpene citral against Aspergillus flavus indicating that when the bioactive chemical penetrates the fungal cell; it causes an irreversible damage to the fungal plasma membrane and the DNA which consequently makes the fungus to fail in spore germination.

In the same vein, Ito et al (2005) also reported that the plant extracts which contains saponin in the form of tomatin forms a complex with fungal membrane sterol with free hydroxyl group and the complex result in pore formation and subsequent loss of fungal membrane integrity.

Another evidence of mechanism of actions of bioactive chemicals on phytopathogenic fungi is that presented by Brostock (1999). This showed that the phenolic compounds in form of chlorogenic acid and caffeic acid which are commonly accumulated in the epidermis and subtending plant cell layers; when compounded as plant extracts, inhibit the formation of oxidase of the attacking pathogen, as reported in Brown rot fungus; Monilia fructicola. Stilbene oxidase is an enzyme synthesized by fungi to render plant phytoalexin (stilbene) effective; so the presence of bioactive compound in plant extract inhibits its formation thereby ensuring safety of the host plant.

Harris and Dennis (1976 and 1977) reported that terpenoid type; a bioactive chemical causes the zoospores of Phytophthora infestans, $P$ porri and $P$ cactorum to develop cytoplasmic granulations disruptions of plasma membrane and leakage of cellular contents.

It was also reported that these mechanisms of actions in the presence of terpenoids was observed in fungal cells treated with isoflavonoids in the form of phaseolin and kelvitone (Vanitten and Batemcm, 1971).It was reported as well that hydroxyl stilbene that occur in form of resveratrol and piceatannol have the potency to inhibit fungal ATpases, resulting in the dissociation of chaperone and cohaperones; the second proteins frequently associated with fungal cytoskeleton (kindl, 2000).

It had been indicated that several alkaloids affect biological actions on fungal pathogens of plants at very low concentrations. Alkaloids in form of allosecurinine contained in plant extracts of Phyllanthus amarus inhibited spore germinations of some fungi such as Heterosporium species, Curvularia lunata and Colletotriclum musal (Andrian et al, 1997; Pezit and pout 1990). This fact was also reiterated by Singh et al, (1995). 
Journal DOI: 10.46654/ij.24889849 Vol. 6, Issue 12 (December, 2020) | www.ijaar.org

For an easy comprehension of the mode of action of plant bioactive chemicals, we do reference the pattern of Zaker (2014) to reflect in a tabular form.

Name Of Bioactive chemical

\begin{tabular}{|l|l|}
\hline \hline 1. Akaloids & $\begin{array}{l}\text { Interact into cell wall for disruptions and leakage of cellular } \\
\text { contents. }\end{array}$ \\
\hline 2. Tannins & $\begin{array}{l}\text { Bind to protein enzymes of the pathogen,to inhibit the enzymes } \\
\text { and cause substrate deprivation. }\end{array}$ \\
\hline 3. Terpenoids & Disrupt the fungal pathogen membrane. \\
\hline 4. Lectins & Form disulphide bridges \\
\hline 5. Flavonoids & $\begin{array}{l}\text { Bind to adhesions, complex with cell wall and inactivate fungal } \\
\text { enzymes. }\end{array}$ \\
\hline 6. Coumarins & Interact with the fungal DNA for disruptions. \\
\hline 7. Polypeptides & Also form disulphide bridges. \\
\hline 8. Essential oils & Disrupt fungal membranes. \\
\hline 9. Simple Phenols & Disruption of membrane and deprive the pathogen of substrates. \\
\hline 10. Phenolic acid & $\begin{array}{l}\text { Bind to adhesion, complex with cell wall and inactivate fungal } \\
\text { enzymes. }\end{array}$ \\
\hline
\end{tabular}

Adapted from Cowan (1999).

\section{Conclusions}

This review supplied among other information, plant species that contain bioactive chemicals, chemicals involved as well as the mode of actions of the chemicals;

The study had shown that the toxicity of the chemicals

(1) Act directly on fungal pathogen

(2) The chemicals deplete ions in the pathogen

(3) Inhibit the attacking fungi enzymes

(4) Can complex with fungal steroids to inhibit spore germinations.

(5) The bioactive chemicals cause damage to the fungal plasma membrane and DNA.

(6) They can make fungi loose their membrane integrity.

(7) Stop the formation of stilbene oxidase of the fungi

(8) They can cause cytoplasmic granulation, disruption of plasma membrane and leakage of celluler contents. Above all, the plant biochemical compounds can inhibit fungal ATPases resulting to the dissolution of fungal chaperone and co haperones; the second proteins of fungal cytoskeleton.

Finally, if these plant bioactive compounds have these great potencies with no risk on the ecosystem nor hazard on consumer's health; then the option of replacing synthetic agrochemicals with plant product formulations fits better with food security policies. Based on this revi'ew, it is recommended that these bio-formations should be used against the elaborate use of field inventories. They are safe biodegrables, ecofriendly alternative to be commercially embraced by farmers to exclude agro-chemicals in the near future. 


\section{References}

Aala, F., Kalson U., Khodavandi, A and Jamal, F. (2010). invitro antifungal Act of allian alone and incombination with two medications against Six dermatophytic fungi. African Journal of Microbiology Res, 4(5):380-385.

Adrian, M., Jeandet, P., Veneay, J.I,. Western, L.A., Besis, R (1977). Biological activity of re; a stilbene compound from grape vines against Botrytis cinerea, the casual agent of grey mould.J.Chem.Ecol, 23:1689-1702.

Afolabi, O.A, and Oke, O.L.(1981) Preliminary study on the nutritive value of some cereal like grains. Nutr. Rep. Int, 24: 389-394.

Agrois, G.N. (2004) Losses caused by Plant diseases. Plant Pathology. Elsevier Oxford U.K

Agrois, G.N. (2005) Plant Pathology, $5^{\text {th }}$ (ed) AP, New York, NY, p.922

Alfren, N. and Van, K. (2001) http://doi.org/10/1038/npg.elson000362

Armah, C.N., Mackie, A.R, Roy, C., Price, K., Osbourn, A.E., Bowyer, P. Ladha, S. (1999) The membrance permeability of avenacin A-1 involves the organization of bilayer cholesterol. Biophys. J, 76: 281-290.

Avasthi, S. Gantam, A.K., and Vhadauria R. (2010). Anti-fungal activity of Plant Products against Aspergillus niger. A Potential application in the control of a Spoilage fungus. Biological forum- An international Journal, 2(1): 53-55.

Balakumar, S. Rajan, S., Thirunala Sundari T., Jeeva, S. (2011). Anti-fungal of Aegle normelos (L) correa (Rutaceae) Leaf extracts on dermatophytes. Asian Pac. J. Tropical Biomed, 1(4): 309-312.

Bar-Num, N. and Meyer, A.M. (1990) cucurbitacins Protect Cucumber tissue against infection by Botrytes cinerea. Phytochem, 29(3): 787-791

Bennett, R.N. and Wallsgrove, R.M. (1994). Transley Review No 72; Secondary metabolites in plants defence mechanisms. New Phytol, 127 : 617-633.

Bostock, P.M., Wilcox, M., Wang, G. Adaskaveg, J.E. (1999). Suppression of Monililia fructicola cutinase Production Produdion by Peach fru surface phendic acids. Physiological molecular Plant pathology, 54 (1-2): 37-50.

Burgeel, Z.J., and Smaglowski, M.(2005). Fungistatyczne wlasciwosci olejku zdrzewa herbacianego (fungistatic properties of tea toree oil). Zesz.Probl.Post.Nank Roln.529: 1318. 
Cosic . J. Vrandecic, K., Postic, J., Jurkovic, D. nd Ravlic, M. (2010). Invitro antifugal activity of essential oils on growth of Phytopathogevic fungi. Polioprivreda, 16 (2): 25-28.

Cotoras, M. Folch, C. Mendoza, L. (2004). Characteristics of anti-fungal activity on B. cinerea of the natural diterpnoids kraurenoic acid 3B-hydroxy-kauronoic acid. J. Agric. Food chem., 52: $\quad$ 2821-2826.

Cowam . M.M . (1999). Plant Products as antimicrobial agents. Microbiology Reviews, 12: 564582.

Croteau, R. Kut chan, T. Lewis. W (2000). Natural Products (Secondary metabolites) In: Buchaman, B. Gruissem W. Joneas, R. (eds), Biochemistry and molecular biology of plant biologists. Rockville, M.D. PP: 1250-1268.

Daferera, D.J., Ziogas, B.N., Polossion, M.G. (2003). The effectiveness of Plant essential oils on the growth of B. Cinerea, Fusarium species and clavibacter Michganensis Subsp Michiganensis. Crop Protection, 22: 39-44.

Daniel, C.K., Lennox, C.L. Vries F.A (2015). In vitro effect of garlic extracts on pathogenic fungi, B. cinerea, Pencillium expansum and Neofaraea alba. S.Afr.J Sci., 111(7/8): 1-8.

Davicino, R., Mattar, M.A., Casali, Y.A Graciela, Margarita, E., Micalizzi, B. (2007). Anti fungal activity of Plant extracts used in folk medicine in Argentina. Revista Peruana de Biologia 14: 247-251.

Davidson, P.M. (1997): Chemical Perspectives and natural anti-nucrobial compound. In: Doyle, M.P, Beuchat, L.R. and Montville, T.J. (eds). Food microbiology, fundamentals and frontiers. Washington D.C. ASM Press, p. 520-556.

Diaz-Dellavella, P.; Cabrera, Andrea; Alem, Diego; Larrariaga Patricia; Ferreira Fernando; and Marco Dalla Riza (2011). Antifungal Activity of Medicinal plant extracts against phytopathogenic fungus alternaria SPP. Chilean Journal of Agricultural Research. 71(2): 231-239.

Dewick, P.M. (2002). Medicinal natural Produces it biosynthetic Approach. John Wiley and sons Ltd... Chichester, UK, $2^{\text {nd }}$ ed. p. 507.

De-lange, J.H., Vicent, A.P., Du Plessis, L.M, Vanwyk, P.J., Ackerman, L.G.J. (1976). Scoparone (6, 7- dimethoxycoumarin) induce in Citrus Peel by black spot, Guigmardia citripaca Kiely, Phytophylactica 8: 83-84.

Eterpi Christaki, Elefthnerios Bonos, Ilias Giannenas and Panagiota Florou Paneri (2012). Aromatic Plants as a source of bioactive compounds. Agriculture, 2: 228-243 
Englemeier, D. and Hadacek, F. (2006). Antifungal natural Products: Assays and applications: in Rai et al (eds). Naturally occuring bioactive compounds, Elsevier Sci Ltd., p. 423-467.

Farombi, E.O (2003). African Indigenous Plants with chemotherapeutic Potentials and biotechnological approach to the production of bioactive Prophylatic agents. African Journal of Biotechnology, 2: 662-671.

Fawzi, E.M., Khalil, A.A. and Afifi, A.F. (2009). Anti-fungal effect of some plant extracts on Alternaria alternate and Fusarium oxysporum. African Journal of Biotechnology, 8 (11): 2590-2597.

Gavaric, N., Mozina, S.S., Kladar, W. and Bozin, B. (2015). Chemical Profile, Antioxident, and Antibacterial Activity of Thyme and Oregano essential oils, Thymol and Oregano and their

possible synergism. Journal of essential oils bearing plants, 18 (4): 1013-1021.

Gnanamickam, S.S. (2002). Biological control of crop diseases. Mercel Dekker Inc. New York, NY,USA: 468.

Gillitzer, P. Martin, A.C., Kauppi, K. Dawberg, S., Lis, D. (2012). Optimization of screening of native and naturalized Plants from Minnesota for antimicrobial activity. J.Med. Plants. Res, 2012(1): 25-29.

Goetz, G. Fkyerat, A., Metals, N. Kuns, M., Tabachi, R., Pezet, R., Pont, V. (1999). Resistance factors to grey mould in grape berries: Identification of some phenolic inhabitors of Botrytis cinerea stibene oxidase. Phytochemistry, 52: 759-767.

Gonen, L.Virlebo, A., cantone, F., Staples, R.C., Mayer, A.M. (1996). Effect of cucurbitacius on MRNA coding for laccase in B. cinerea. Photochemistry, 42:321-324.

Hadacek, F. (2002). Secondary metabolites as Plant traits. Current assessment and future Perspectives. Crit.nev. SCI 21: 273-322.

Hadian,S. (2012): Anti-fungal activity of some Plant extracts against some plant Pathogenic fungi in Iran. Asian Journal of Experimental Biological Sciences, 3(4) PP: 714-718.

Hamowia, A.M. and Safran, A.M. (1994). Pharmacological studies on Vernonia amydalina (Del) and Tithonia diversifolia I(Gray) Vot. med., 42:91-97.

Harris, J.E and Dennis, C. (1976). Antifungal activity of Post-infectional metabolites from potato tubers. Physiol. Plant Pathol, 9:155-165.

Harris, J.E. and Dennis, C. (1977): The effect of post inflectional Potato tuber metabolites and surfactants on zoospores of Comycetes. Physiol. Plant Pathol, 11: 163-169. 
Harris, C.A., Renfrew, M.J. and woodridge M.W. (2001). Assessing the risk of pesticides residues to consumers: recent and future development. Food additives and contanunation, 18:1124-1129.

HOF, H. (2001). Guest commentary: Critical annontations to the use of azole antifungals for plant Protection. Anti-Microbial Agents. Chemother 45(11): 2987-2990.

Ikpeme, Emmanuel Maunday; Alobi, Nor Odo; Enyi-Idoh, Kingsley Hovana; Okoi, Arikpo Ikpi, Etim, Kimboline Donatus; Ejar Mattew Egbobor (2013). The Phytochemical and antimicrobial studies of Ficus exasperate and cida acuta on Staphlococcus aureus and Esherisha coli. Central European Journal of Experimental Biology. 2(2) : 1-4.

Ito, S., Nagata, A., Kai, T., Takahara, H. and Tanaka, S. (2005). Symptomless infection of tomato Plants by tomatinase Producing Fusarium oxysporum formae speciales non Pathogenic on tomato plants. Physiological and Molecular Plant Pathology, 66(5):183191.

Jalili-Marandi, R., Hassani, A. Ghosta, Y., Abdollahi, A., Pirad, A. Sefidkon, F. (2010). Thymus Kotschyanus and carum fungitoxic Properties to Phytopathogenic fungi of essential oils of selected aromatic plants growing wild in Turkey. Journal of Agricultural and food chemistry, 43: $\quad$ 2262-2266.

Jeandet, P., Dowillet, A., Bessis, R., Debord, S. Sbaghi, M., ANdrian, M. (2002). Phyloalexens from Vitaceae biosynthesis, Phytoalexgene expression in transgenic Plants anti-fungal activity and metabolism. Journal of Agricultural food and Chemistry, 50: 2731-2741.

Jasso de Rodriguez, D., Trejogonzalez, F.A., Rodriguez-Gercia, R., Diaz- Jimenez, M.L.V., Saenz- Garlindo, A., Hernadez-castillo, F.D., Villarreat-Quintanilla, J.A., Pena Ramos, F.M. (2015). Anti-fungal activity invitro of Rhus muelleri against $F$. Oxysporum f. SP Lycopersia. Industrial crop Production, 75: 150-158.

Keukens, E.A.J., De Urije, T. Van DenBoom.C., De waard, P., Chupiri, V. Jogen, W.MF., De Kruijff, B. (1995). Molecular basis of glycoalkaloids induced membrane disruption. Biochemistry. Biophysics Acta, 1240: 216-28.

Kimberly D. Gwinn (2018). Bioactive natural Products in Plant disease controls. Studies in natural Products Chemistry. www.researchgate.net

Korres, A.M., Buss, D.S., Ventura, J.A. Fernandes, P.M.B. (2011). Candida Krusei and Kloekeraapis inhibit the caused agent of Pineapple fusariosis, Fusarium guttiforme. Fungal Biology, 115:1251-1258.

Lee, S.O., Gyoung, J.C., Kyoung, S.J., He Kyoung, L; Kwang,, Y.C. and Jin-Cheol, K. (2007). Antifugal activity of five Plant essential oils as fumigants against Post-harvest and soilborne 
Plant Pathogenic fungi. Plant Pathology Journal, 23 (2): 27-102.

Marin, S. Velluti, A., Ramos, A.J. and Sanchis, V. (2004) Effect of essential oils on Zearalenone and deoxynivalend Production by Fusarium graminearum in non sterilized maize grain. Food microbiology. 21:313-318

Martinez, J.A. (2012). Natural fungicides obtained from plants. In: Fungicides for plants and

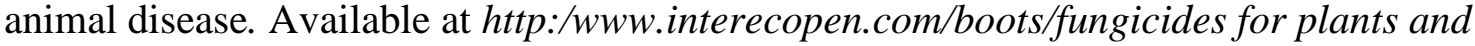
animals/Natural fungicides obtained from plant.

Luo, M. Jiang, L.K. and Zou, G.L.(2002). The mechanism of loss of germination ability of Aspergillus flavus spore with citral. Zhongguo Shengwu Huaxue Yu Fenzi Shengwu Xuebao. Chem. Abs, 137, 60144.

Nashwa, S.M.A and Abo-Elyousr, K.A.M. (2012). Evaluation of various Plant against the early blight disease of tomato plants under greenhouse and field condition. Plant Protection Science, 48. (2):74- 79.

Nmom, F.W. and Ajuru, M.G. (2019). Efficacy of crude leaf extracts of ficus exasperata (Vahl) in the control of Powdery mildew on Vernonia Amydalina(Del). Presented at the $11^{\text {th }}$ Annual and Scientific Conference of Mycological Society of Nigeria (MYCOSON), Port Harcourt.

Numpaque, M.A., Oviedo, L.A., Gil, J.H., Garcia, C.M. and Durango, D.L.(2011) Thymol and cavacrol: biotransformation and antifungal activity against the Plant Pathgenic fungi; Colletotrichum acutatum and Botrydioplodia theobromae. Tropical Plant Pathology 36(1) : 3-13.

Okogbule, F.N.C and Chuku, E.C. (2020). Effects of treatment with different Plant material on shelf life of groundnut Paste. Presented at the $45^{\text {th }}$ Annual conference and $50^{\text {th }}$ Anniversary, Uniuyo, 2020 PP: xci.

Pattnaik, M.M., Kar, M., Sahn, R.K.(2002) Bio-efficiency of some Plant extracts on growth parameters and control of diseases in Lycopersicum exculnrum. Asian Journal of Plant science .and research, 2 (2): 129-142.

Pezet, P. and Pont, V. (1990). Ultrastructural observation of Plerostilbene fungitoxicity in dormant conidia of B. cinerea. Pers. J. Phtopathology, 129:27-30.

Riad, S.R., El- Mohamedu and Abdallah, A.M.(2014). Antifungal activity of Moringa oleifera oil and seed extract against some Plant pathogenic fungi. Middle East Journal of Agriculture Research 3(2): 242-249. 
Rocha, L. (2000). Preparation of Tinctures for homeopathic use In: Sharapin N. Rocha, L.M., Carvallio, E.S, Lucio, EMRA dos Santos EVM, de Almeida J.M.L. editors; Technology fundamentals of herbal Products. Santa fe de Bogota, 63-72.

Romanazzi, G., Lichter, A. Gabler,, F.W. Smilanick J.L(2012). Recent advances on the use of natural and safe alternatives to conventional methods to control Post harvest grey mold of table grapes. Post harvest Biology and Technology, 63:141-147.

Satish, S., Mohana, D.C., Raghavendra, M.P. and Raveesha, K.A.(2007). Antifungal activity of some Plant extracts against important seed -borne pathogens of Aspergillus SPP. Journal of Agricultural Technology, 3(1):109-119.

Singh, R.S., Jindal, A., Singh, D., Singh T. (1995). Selection of Trichoderma isolates against common fungicides for their use in integrated Plant disease management. Indian $\mathrm{J}$. Mycol-Pl-Pathol, 25(1): 127-128.

Sayago, J.E., Ordonez, R.M., Negrillo, L. Torres, S., Isla, M.I. (2012). Antifungal activity of extracts of extremophile plants from the Argetine Puna to control citrus/harvest and Green mold. Plant Biotechnology Ailment, 33(1): 40-46.

Shin, M.H., Kim, J.H., Choi, H.W., Keum, V.S., and Chum, S.C. (2014). Effect of Thymol and linalool fumigation on Post harvest diseases of table grapes. Mycobiology 42(3): 262268.

Thangavelu, R., Ganga, P., Gopi, M., Mustaffa, M.M (2013) Management of eumusae leaf spot disease of banana caused by Mycosphaerella eumusae with Zimmu (Aluim sativum $x$ A.copa) leaf. Ext. Crop Proct., 46:100-105.

Thompson, L. (2002). Antifungicide. Rev chil infectol, 19(1): 22-25.

Trosken, E.R., Scholz, K. Lutz, R.W., Volkel, W.zarn, J.A., Lutz,W.K(2004). Comparative assessment of the inhibition ofr recombinant. human cypia (Aromatase) by azoles used in agriculture and as drugs for humans. Endo cr Res, 30(3): 387-394.

Tscio, R and Zhou, T. (2000). Antifungal activity of monoterpenoids against post harvest pathogens; Botrytis cinerea and Monilinia fructicola. Journal of Essential oils Research, 12:113-121.

Tzortzakis, N.G. Economakis, C.D (2007). Antifungal activity of lemongrass (cymbogoncetratus L.). essential oil against key Postharvest Pathogens. Innov. Food Sci Energy Technol, 8(2): 253-258.

Van Ethan, H.D. and Bateman, D.F. (1971). Studieson the mode of action of phaseolin. Phytopathology, 61: 1363-1372. 
International Journal of Advanced Academic Research (Sciences, Technology and Engineering) | ISSN: 2488-9849

Journal DOI: 10.46654/ij.24889849

Vol. 6, Issue 12 (December, 2020) | www.ijaar.org

Article DOI: 10.46654/ij.24889849.e61240

Villanueva Bermejo, D., Angelov, I., Vicente,G., Stava, R., Rodriguez Garcia-Risco, M., Reglero, G., Ibanez,E., and Fornari, T: (2015). Exttraction of Thymol from different varieties of thyme Plants using green solvents. Journal of the science food and Agriculture 95(14):2901-2907.

Zaker, M and Mosallanejad, H. (2010). Antifungal evaluation of some Plant extracts in controlling Fusarium Solani, the causal agent of potato dry rotin vitro and invivo. International Journal of Agriculture and Biosciences,3(4): 490-195.

Zaker, M.(2014). Anti-fungal evaluation of some Plants extracts, the causal agent of allernaria leaf spot of Potato. Pakistan Journal of Biological Sciences 13(21):1023-1029. 